Animal Health Research Institute,

Assiut Regional Laboratory.

\title{
PREVALENCE OF LISTERIA MONOCYTOGENES IN RAW AND COOKED POULTRY WITH RAPID CONFIRMATION BY MULTIPLEX PCR.
}

(With 3 Tables and One Figure)

\author{
By \\ GHADA M. MOHAMED and LUBNA M. EBRAHEEM
}

(Received at 15/12/2011)

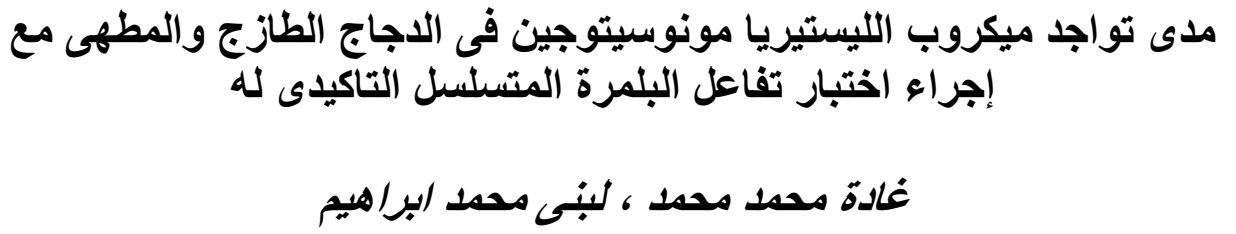

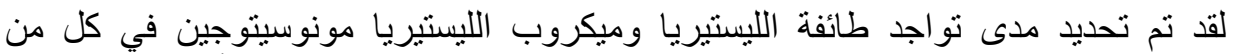

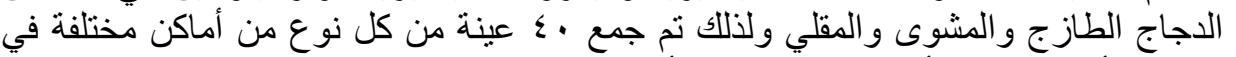

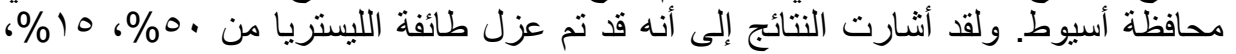

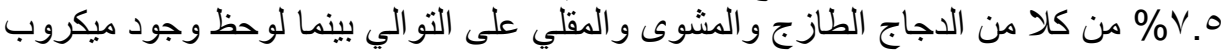

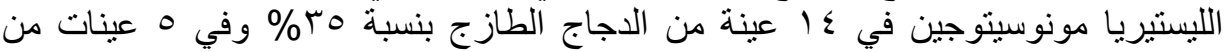

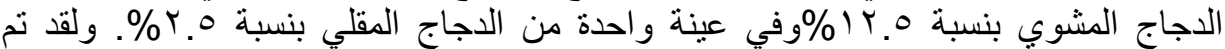

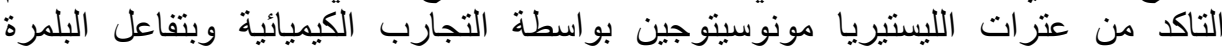

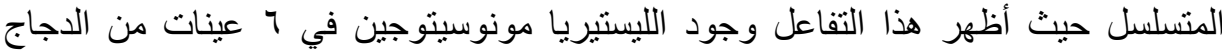

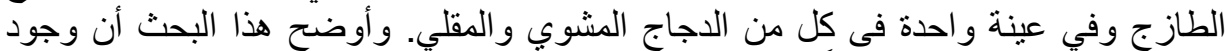

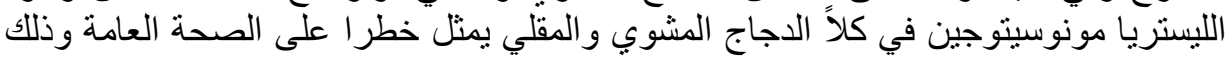
للاقبال الكبير و الاستهلاك البومي لهذه المناج النتجات.

\section{SUMMARY}

The incidence of Listeria spp. and Listeria monocytogemes in raw, grilled and fried poultry was determined, 40 samples of each product wich were collected from different localities in Assiut City. The obtained results pointed out that Listeria spp. could be isolated from 50, 15 and $7.5 \%$ of the examined raw, grilled and fried poultry respectively, while(20)of Listeria momocytogenes was detected in $14(35 \%)$ of raw 
poultry, $5(12.5 \%)$ of grilled samples and $1(2.5 \%)$ of fried samples. Strains of Listria monocytogenes was characterized by several biochemical tests and confirmed by polymerase chain reaction (PCR). Results showed that Listeria moncytogenes was confirmed by PCR in 6 isolates of raw poultry and one from each of fried and grilled samples. This study revealed that presence of Listeria monocytogenes in both grilled and fried poultry is an important public risk because of the great demand for daily consumption of these products.

Key words: Listeria monocytogenes, raw poultry, cooked poultry, PCR.

\section{INTRODUCTION}

The bacterium Listeria monocytogenes is gram-positive, motile organism capable of growth between -0.4 and $50^{\circ} \mathrm{C}$ and due to its ubiquitous character, Listeria monocytogenes easily enters the human food chain and may multiply rapidly (Farber and Peterkin, 1991).

Recent studies have confirmed the presence of Listeria monocytogenes in a wide variety of food stuffs. Milk (mainly unpasteurised), dairy products (especially soft ripened cheeses), poultry meat and their products and raw vegetables are considered to be the most frequently contaminated with Listeria (FAO, 2000).

The association between the consumption of cooked poultry products and several cases of listeriosis in England and the United States, together with the finding that Listeria monocytogenes was present in $12-27 \%$ of such products, indicates that ready to-eat food may constitute a public health risk (Kaczmarski and Jones, 1989). The presence of microorganisms in ready to eat food is a result of lack of hygiene because Listeria monocytogenes was noticed in slaughter animals and human faeces (Furowicz, 1992). The heating processes as cooking and pasteurization should eliminate Listeria.

Most healthy humans are not significantly affected by the intake of small numbers of Listeria monocytogenes in foods. However, certain sections of the population are predisposed to the development of listeriosis due to the presence of existing chronic illness, suppression of the immune system, pregnancy, or extreme youth or age under 1 year or over 60 years (Lorber, 1990). This presents a significant public health problem because in such section of the population, listeriosis is fatal in up to $30 \%$ of cases (Farber and Peterkin, 1991; Jones and MacGowan 
1995).

Because of the public health significance of Listeria monocytogemes, the present study was undertaken to determine the prevalence of the organism in both raw and cooked poultry with using multiplex PCR as a rapid, specific and reliable means for identification of the organism.

\section{MATERIALS and METHODS}

\section{Collection of samples:}

One hundred and twenty samples of poultry were examined: 40 raw, 40 grilled and 40 fried poultry samples were collected from different slaughter establishment and different restaurants in Assiut City. The samples were analyzed on the day they were collected for isolation of Listeria monocytogenes according to FDA (2011).

\section{Isolation}

$25 \mathrm{~g}$ of each sample were aseptically added to $225 \mathrm{ml}$. Listeria Selective Enrichment broth (LSEB) and mixed thoroughly then incubated at $30^{\circ} \mathrm{C}$ for $24-48 \mathrm{~h}$. and next the broth was cultured on Oxford Agar. After $24-48 \mathrm{~h}$ of incubation at $35^{\circ} \mathrm{C}$ the colonies morphologically resembling Listeria were submitted to confirmatory examination.

\section{Identification}

Suspected Listeria colonies (black with black halo on esculincontaining media and blue on Aloa agar media) were examined by Gram stain, for shape, arrangement of bacteria and its staining reaction. The organism was cultured onto semisoled media to observe umbrellashaped motility, haemolysis on sheep blood agar and CAMP test, (Quinn et al., 1994)

For further confirmation of Listeria monocytogenes, the isolates were inoculated into $0.5 \%$ carbohydrate broth fermentation media of Mannitol, L-Rhamnose, D-xylose and dextrose.

Nine strains for which expressing these standard features were selected ( 7 strains from raw poultry and one strain from each of grilled and fried poultry) and examined according to PCR technique.

\section{DNA extraction:}

Total DNA was obtained from the nine selected strains of confirmed isolates. Each strain was incubated overnight in Tryptose Soya Broth and the bacteria from $1 \mathrm{ml}$. of this culture were centrifuged 
and the pellet was resuspended in $100 \mathrm{ml}$ of distilled water. Then $100 \mathrm{ml}$ of $2 \%$ triton X-100 were added. The contents were incubated at room temperature for $10 \mathrm{~min}$ and the tubes were boiled for next $10 \mathrm{~min}$. following incubation, the tubes were centrifuged for $5 \mathrm{~min}$ at 13.000xg. DNA containing supernatant was used in PCR. (Agresborg et al., 1997).

\section{Oligonuceoltide:}

For identification of Listeria monocytogenes using RCR, two oligonuceoltide primers were selected based on the PrFA (transcriptional activator of the virulence factor) gene for Listeria monocytogenes, as described by Germini et al. (2009).

Table 1: Oligonucleotide sequences used for identification of Listeria monocytogenes by PCR.

\begin{tabular}{|c|l|c|c|}
\hline $\begin{array}{c}\text { Target } \\
\text { gene }\end{array}$ & \multicolumn{1}{|c|}{ Primer sequence (5'-3') } & $\begin{array}{c}\text { Amplified } \\
\text { fragment } \\
\text { length }\end{array}$ & Reference \\
\hline $\begin{array}{c}\text { PRFA } \\
\text { gene }\end{array}$ & $\begin{array}{l}\text { LIS-F:TCA TCG ACG GCA ACC } \\
\text { TCG G } \\
\begin{array}{l}\text { LIS-R:TGA GCA ACG TAT CCT } \\
\text { CCA GAG T }\end{array}\end{array}$ & $\begin{array}{c}\text { Germini } \\
\text { et al. (2009) }\end{array}$ \\
\hline
\end{tabular}

\section{PCR reaction conditions:}

The PCR was performed in total volume of $25 \mu 1$, using $2 \mu \mathrm{l}$ of extracted DNA as template. Each reaction mixture contained $12.5 \mu 1$. GoTag Green Master Mixture (Promega, M 7122), $1 \mu 1$ of 500 Pmol Forward primer (LIS-F), $1 \mu 1$ of 500 Pmol reverse primer (LIS-R) and $8 \mu 1$ of ultra-Pure DNase/ RNase -Free Distilled water (Gibco, Grand Island, Ny, USA). All tubes were overlaid with liquid parafin (2 drops) to avoid evaporation during thermal cycling, (Ependrof thermal cycler, Germany)

\section{Amplification:}

DNA was amplified by temperatue cycling through the following temperature profile: preincubation at $95^{\circ} \mathrm{C}$ for $5 \mathrm{~min}, 40$ cycles of $95^{\circ} \mathrm{C}$ for $30 \mathrm{~s}$ (denaturation), $54^{\circ} \mathrm{C}$ for $30 \mathrm{~s}$ (annealing) and $72^{\circ}$ for $30 \mathrm{~s}$ (amplification), with a final cycle extending amplification conditions to $72^{\circ} \mathrm{C}$ for $5 \mathrm{~min}$.

Amplified products were kept at $4^{\circ} \mathrm{C}$ and resolved by horizontal 
agarose gel electrophoresis $1 \%$, gels were stained by immersion in $2 \mu 1$ ethidium bromide solution for $30 \mathrm{~min}$, washed briefly in running tap water, then detected under a short-wavelength UV light and photographed with EDVOTEK Gel documentation system (Germini et al., 2009). The 1-KB plus DNA ladder (Invitrogen) was used as molecular size marker.

\section{RESULTS}

The obtained results were recorded in Tables 2 and 3.

Table 2: Prevalence of Listeria spp. and Listeria monocytogenes in raw, grilled and fried poultry samples.

\begin{tabular}{|l|c|c|c|c|c|}
\hline \multirow{2}{*}{ Type of samples } & \multirow{2}{*}{$\begin{array}{c}\text { No. of } \\
\text { examined } \\
\text { samples }\end{array}$} & \multicolumn{2}{|c|}{$\begin{array}{c}\text { +ve samples of } \\
\text { Listeria.spp }\end{array}$} & \multicolumn{2}{|c|}{$\begin{array}{c}\text { +v samples of } \\
\text { L.monocytogenes }\end{array}$} \\
\cline { 4 - 7 } & & No & $\%$ & No & $\%$ \\
\hline Raw poultry & 40 & 20 & 50 & 14 & 35 \\
\hline Grilled poultry & 40 & 6 & 15 & 5 & 12.5 \\
\hline Fried poultry & 40 & 3 & 7.5 & 1 & 2.5 \\
\hline Total & 120 & 29 & 24.2 & 20 & 16.6 \\
\hline
\end{tabular}

Tables 3: Results obtained in multiplex PCR.

\begin{tabular}{|l|c|c|c|}
\hline \multicolumn{1}{|c|}{$\begin{array}{c}\text { Type of } \\
\text { samples }\end{array}$} & $\begin{array}{c}\text { No.of isolated } \\
\text { strains of } \\
\text { L.monocytogenes }\end{array}$ & $\begin{array}{c}\text { No.of strains } \\
\text { confirmed } \\
\text { byPCR }\end{array}$ & $\begin{array}{c}\text { No.of +ve strains } \\
\text { out byPCR }\end{array}$ \\
\hline Raw poultry & 20 & 7 & 6 \\
\hline Grilled poultry & 6 & 1 & 1 \\
\hline Fried poultry & 3 & 1 & 8 \\
\hline Total & 29 & 9 & 1 \\
\hline
\end{tabular}

\section{Identification by PCR:}


Fig. 1: agarose gel electrophoresis of amplication products obtained from genomic DNA of Listeria monocytogenes isolated from the examined samples (217 bP PCR product).

Lane I: Molecular size marker.

Lane 2-10: +ve positive for Listeria monocytogenes except lane six with is negative for Listeria monocytogenes.

Lane 11: Positive control. (Obtained from Department of Medicine Microbiology, College of medicine-Assiut)

Lane 12: Negative control.

\section{DISCUSSION}

Cooking is the process of producing safe and edible foods.It is clear that cooking has been around for a long time and continues today to play a fundamental role in daily life across the globe. Cooking was first used for preservation but it has evolved and now it is a form of entertainment and creativity for many people. The fundamental types of 
cooking are grilling and frying. Grilling is cooking of food using a direct dry heat while frying is the cooking of food in oil or fat. Common types of food that are grilled and fired include fish, meat and chicken (EUFIC 2010).

Fried chicken is an important food served at almost all fast foods restaurant chains. Surface appearance and texture are the most significant factors for consumer acceptability. Most foods cook rapidly and develop golden colour, crisp texture and good flavour at the frying temperatures between 160 and $90^{\circ}$ (EUFIC 2010).

As shown in Table 2, 20 of 40 raw poultry meat (50\%) were found to contain Listeria spp. This trend is higher than that recorded by Mahmood et al. (2003) (12.5\%) and Lihan (2007) (34.8) while Lorna and Arthur (1994) and Katarzyna et al. (2004) recorded higher percent of Listeria spp. than our study (91 and 61.4\%, respectively).

From the same table the incidence of Listeria monocytogens in raw poultry $(35 \%)$ was higher than that obtained by Marinsek and Grebenc (2002) (15.78\%), Mahmoood et al. (2003) (5\%), Gudbjornsdottir (2004) (22.2\%), Katarzyan et al. (2005) (13.9\%), Hindy (2006) (8\%), lihan (2007) (24.1\%) while Ashraf et al. (2010) couldn`t isolate Listeria monocytogenes from any of 25 samples of frozen breast fillet examined.

On the other hand, higher result are recorded by Rama et al. (1994) (60\%), Lorna and Arthur (1994) (59\%), Miettinen et al. (2001) (62\%) and Cristina et al. (2004) (60\%). While other investigations of poultry meat obtained by some authors confirmed our results, they recorded nearly similar percentage as Uyttendele et al. (1999) (38.2\%), Capita et al. (2001) (32\%) and Vitas et al. (2004) (36.1\%).

Several studies showed that rates of Listeria monocytogenes in raw chicken varied between 23\% and 60\% (Pini and Gilbert, 1988; Skovgaard and Morgan, 1988).

The presence of Listeria monocytogenes in raw poultry cannot be considered as important as in grilled and fried one since raw poultry are normally cooked or pasteurized before consumption. It has been demonstrated that normal pasteurization processes are effective in the destruction of this pathogen so conventional cooking would also be expected to eliminate this organism (Norrung, 2000).

From the tabulated data in Table 2, the percentage of Listeria spp. in grilled poultry was $15 \%$, which is somewhat in agreement with that of Wilson (1995) who recorded an incidence of $11 \%$ in ready to eat chicken. As for fried poultry $7.5 \%$ contained Listeria spp. which is 
nearly similar to the results detected by Lorna and Arthur (1994) who noticed the organism in $8 \%$ of cooked poultry.

Listeria monocytogenes as presented in Table 2 was recovered from $12.5 \%$ of grilled poultry, while Diaz-lopez et al. (2011), could not detect the same organism in the same product. Also this table revealed that $2.5 \%$ of Listeria monocytogens were isolated from fried poultry, whereas Meldrum et al. (2010) reported the isolation of the organism from $0.19 \%$ of chicken sandwiches (fried chicken).

On the other side, the obtained results were in disagreement with Lorna and Arthur (1994) and Katarzyna et al. (2005) who could not detect the organism in cooked poultry.

It is worth to mention that previous surveys on cooked and ready to eat poultry, showed that 12 to $27 \%$ of the samples were found to contain Listeria monocytogenes (Gilbert et al., 1989; Kerr et al., 1990; Ribeiro and Burge, 1992). In addition Rama et al. (1994) and Tareq et al. (2010) could detect the organisms in $22 \%$ of ready to eat chicken and in $7.8 \%$ in chicken shawirma (fried chicken) respectively.

In this study presence of Listeria monocytogenes in both grilled and fried poultry products may be due to spreading the organism by contact with infected surface or product during food preparation or may be due to insufficient cooking. Various researchers clamed that, poor hygiene practice and cross-contamination between raw and cooked products during food handling is one of the major factors for the outbreak of food borne illness (Schuchat et al., 1992; Salvat et al., 1995; Speirs et al., 1995; Scott, 1996).

It is recommended that, application of good hygienic measures during preparation and good handling is essential to safe the quality of cooked poultry. In addition poultry should be cooked to an internal temperature of $70^{\circ} \mathrm{C}$ for more than 20 minutes to ensure destruction of Listeria monocytogenes confirmed by PCR.

Amplification products obtained when the genomic DNA from these strains were subjected to PCR by using two primer sequences, 8 out 9 tested strains samples were displayed the characteristic PCR product at $(217 \mathrm{pb})$, that Listeria monocytogenes were confirmed in 6 raw poultry, 1 grilled sample and 1 fried sample (Table 3 ). 


\section{REFERENCES}

Agersborg, A.; Dahl, R. and Martinez, I. (1997): Samples preparation and DNA extraction procedures for polymerase chain reaction identification of Listeria monocytogenes in seafoods. Int. J. Food Microbiol. 35: 275-280.

Ashraf, M.A.; Sohaila, F.H.; Raafat, H.; Moemen, A.M. and Khalid, I.E. (2010): Occurrence of Listeria spp in meat, chicken products and human stools in Assiut city, Egypt with PCR use for rapid identification of Listeria monocytogenes Veterinary World Vol. 3 (8): 353-359.

Capita, R.; Alonso-Calleja, C.; Moreno, B. and Garcia-Fernandez, M.C. (2001): Occurrence of Listeria spp. in retail poultry meat and comparison of a cultural immunoassay for their detection. Int. J. Food Microbiol. 65: 75-82.

Collee, J.G. and Miles, R.S. (1989): Tests for identification of bacteria Mackie and McCarthey practical Medical Microbiology, J.G. collee, J.P. Duguid, A. G. Fraser and B.P. Marmion (eds). Vol. 11, 13 ed. Churchill living stone Edinburgh. London, PP: 141-159.

Cristina, M.; Goncalo, A.; Luisa, C.; Paula, T.; Tim, H. and Paul, A.G. (2004): Incidence of listeria monocytogenes in different food products commercialized in Portugal. Food Microbiology, 21: 213-216.

Diaz. Lopez, A.; Cantu-Ramirez, R.C; Garza-Gonzalez, E.; Ruiz. Tolention, L.; Tellez-Luis, S.J.; Rivera, G. and Bocanegragarcia, $V$. (2011): Prevalence of foodbone pathogens in grilled chicken from street vendors and retail qutlets in Reynosa, Tamaulipas, Mexico. J. of Food Protection 74 (8): 1515-1518.

European Food Information Council (2010): The why, how and consequences of cooking our food. Cooking Review-part 1: Introduction.

FAO (2000): Risk assessment; Listeria monocytogenes in ready to eat foods pp. 17-21.

Farber, J.M. and Peterkin, P.I. (1991): Listeria monocytogenes, a foodborne pathogen. Microbiolgical Review 55: 476-511.

Food and drug administration, FDA (2011): Bacteriological Analytical Manual $8^{\text {th }}$ Edition (BAM), Detection and Enumeration of Listeria monocytogenes. chapter 10.

Furowicz, A.J. (1992): New Look on etiopathogenesis of listeriosis. II. 
Epidemiology aspects Medycyna wet. 48: 309-311.

Germini, A.; Masola, A.; Carnevali, P. and Marchelli, R. (2009): Simultaneous detection of Escherichia coli O 175: H 7, Salmonella spp. and Listeria monocytogenes by multiplex PCR. Food Control 20 (8): 733-738.

Gilbert, R.J.; Miller, K.L. and Roberts, D. (1989): Listeria monocytogenes and chilled foods. Lancet 1: 383-384.

Gudbjornsdottir, B.; Suihko, L.M.; Gustavsson, P.; Thorkelsson, G.; Salo, S.; Sioberg, A.M.; Niclasen, O. and Bredholt, S. (2004): The incidence of Listeria monocytogenes in meat, poultry and seafood in the Nordic countries.Food Microbiol., 21: 213-216.

Hindy, B.A. (2006): Further studies on Listeria organisms. Ph. D. Thesis, Fac. Vet. Med. Cairo University, Egypt.

Jones, E.M. and MacGowan, A.P. (1995): Antimicrobial chemotherapy of human infection due to Listeria monocytogenes. European J. of Clinical Microbiology and Infections Disease. 14: 165-175.

Kaczmarski, E.B. and Jones, D.M. (1989): Listeriosis and ready cooked chicken. Lancet i: 549.

Katarzyna, K.P.; Jacek, B.; Jaroslaw, B.; Jerzy, M. and Malgorzata, C. (2005): Occurrence of Listeria spp. In raw poultry meat and poultry meat products. Bull. Vet. Inst. Pulawy 49: 219-222.

Kerr, K.G.; Rontowa, N.A. Hawkey, P.M. and Lacey, R.W. (1990): Incidence of Listeria Spp. In precooked chilled chicken products as determined by culture and enzyme linked immunoassay (ELISA). J. Food Portection. 53: 606-607.

Lihan, S. (2007): Prevalence and characterization of Listeria monocytogenes isolated from chicken and Beef. Ph.D. Thesis, University Putra Malaysia.

Lorber, B. (1990): Clinical listeriosis-imlications of pathogenesis in foodborne listeriosis ed. Miller, A.J. Smith, J.L. and Smokuit, G.A. New York: Elsevier Science, pp. 41-49.

Lorna, M.L. and Arthhur, G. (1994): Incidence of Listeria spp. and Listeria monocytogenes in a poultry processing environment and in poultry products and their rapid confirmation by Multiplex PCR. Applied and Environmental Microbiology 60 (12): 4600-4604.

Mahmood, M.S.; Ahmed, A.N. and Hussain, I. (2003): Prevalence of Listeria momocytogenes in poultry meat, poultry meat products and other related inanimates at Faisalabad. Pakistan Journal of Nutrition, 2 (6): 346-349. 
Marinsek, J. and Grebenc, S. (2002): Listeria monocytogenes in minced meat and thermally untreated meat products in Slovenia. Solvenian Veterinary Research, 39 (2): 131-136.

Meldrum, R.J.; Ellis, P.W.; Mannion, P.T.; Halstead, D. and Garside, J. (2010): Prevalence of Listeria monocytogenes in ready-to-eat foods sampled from the point of sale in Wales, United Kingdom. J. Food Protection.73 (8): 1515-1518.

Miettinen, H.K.; Palmu, L.; Bjorkroth, K.J. and Korkeala, H. (2001): Prevalence of Listeria monocytogenes in broilers at abbatoir, processing plant and retial level. J. Food Protection 64: 994-999.

Norrung, B. (2000): Microbiological criteria for Listeria monocytogenes in foods under special consideration of risk assessment approaches. Int. J. Food Microbiol. 62: 217-221.

Pini, P.N. and Gilbert, R.l. (1988): The occurrence in the Uk of Listeria spp. in raw chickens and soft cheeses. Int. J. Food Microbiol, 6: 317-326.

Quinn, P.J.; Cater, M.E.; Markey, B. and Carter, G.R. (1994): Clinical Veterinary Microbiology. Wolfe publishing Co. London, PP: 170-174.

Rama, K.A.; Gulam, R.; Rahamat, A. and Nudzriah, B.A. (1994): Prevalence of Listeria monocytogenes in food in Malysia. International of Journal of Food Microbiology. 23, 1: 117-121.

Ribeiro, C.D. and Burge, S.H. (1992): Developing microbiological guidelines for food: frist results from cooked chicken portions. Public Heal Lab Serv. Microbiol. Digest. 9: 100-102.

Salvat, G.; Toquin, M.T.; Michel, Y. and Colin, P. (1995): Control of Listeria monocytogenes in delicatessen industries. The lessons of a listeriosis outbreak in france Int. J. Food Microbiol. 25: 75-81.

Schuchat, A.; Deaver, K.A.; Wenger, J.D.; Plikaytis, B.D.; Rengold, A.L. and Broome, C. (1992): Role of Foods in sporadic listeriosis. J. Am. Med. Assoc. 276. 2041-2045.

Scott, E. (1996): Food borne disease and other Hygienic Issues in the Home, J. of Applied Bacteriology 80 (1): 5-9.

Skovgaard, N. and Morgen, C.A. (1988): Detection of Listeria spp. In faeces of farm animals, in feeds and in raw foods of animal origin. Int. J. Food Microbiol. 6: 229-242. 
Speirs, J.P.; Anderton, A. and Anderson, J.G. (1995): A study of the microbial content of the domestic kitchen. International J. of Environmental Health Research. 5 (2): 109-122.

Tareq, M.O.; Akram, R.A. and Ehab, A.N. (2010): Prevalence of Listeria spp. and antibiotic susceptibility of Listeria monocylogenes isolated from raw chicken and ready-to-eat chicken products in Jordan. Food Control. 22, 2-3: 586-590.

Uyttendaele, M.; Troy, P.D. and Debevere, J. (1999): Incidence of Listeria monocytogenes in different types of meat products on the Belgian retial market. Int. J. Food Microbiol. 53: 75-80.

Vitas, A.L.; Aguado, V. and Garcia-Jalon, I. (2004): Occurrence of Listeria monocytogenes in fresh and processed foods in Navarra (Spain). Int. J. Food Microbiol. 90: 349-356.

Wilson, I.G. (1995): Occurrence of Listeria spp. In ready to eat food. Epidemiology and Infection. 115: 519-526. 